\title{
TINJAUAN TENTANG BELIUNG PERSEGI DARI LUMAJANG
}

\author{
Oleh: Truman Simanjuntak
}

\section{PENDAHULUAN}

Di sekitar tahun 1982, tim dari Balai Arkeologi Yogyakarta/Proyek Penelitian Purbakala Daerah Istimewa Yogyakarta mengadakan penelitian di situs perbentengan Biting, Lumajang, Jawa Timur. Pada waktu itu tim mendapat informasi dari Moelyono BA, Kepala Seksi Kebudayaan; Kantor Departemen Pendidikan dan Kebudayaan Lumajang yang ikut serta dalam penelitian tersebut tentang adanya koleksi beberapa beliung di instansinya. Tertarik pada informasi ini, penulis bersama Moelyono, Widya Sarsono, dan Ngadimin (anggota tim) menyempatkan diri meninjau koleksi tersebut. Dalam peninjauan tersebut, kelompok kecil ini mengadakan perekaman (deskripsi, pengukuran, dan pemotretan) terhadap masing-masing koleksi.

Koleksi yang dimaksud meliputi sebanyak 15 buah alat yang termasuk dalam kategori beliung persegi|ditambah dengan sebuah batu asah. Benda-benda ini diperoleh dari penemuan-penemuan penduduk secara kebetulan di kala mengerjakan tegalan. Daerah penemuan meliputi Kecamatan Senduro, Kecamatan Sukodono (Kab. Lumajang), dan Kecamatan Klakah (Kab. Probolinggo). Keseluruhan daerah ini merupakan tetangga satu sama lain dan terletak di sebelah timur Gunung Semeru atau di sebelah tenggara Gunung Bromo. Keadaan daerahnya agak berbukit di Senduro dan semakin datar ke arah Klakah dan Sukodono.

Mengingat pentingnya benda-benda arkeologis ini sebagai sumbangan data untuk distribusi beliung pada khususnya dan penelitian arkeologi pada umum- 
nya, maka penulis mencoba mengetengahkannya dalam kesempatan ini. Pembicaraan akan lebih menitik beratkan perhatian pada bentuk yang mengacu pada tipologi dan teknologi, sedang aspek lainnya tidak memungkinkan dibahas dalam kesempatan ini mengingat benda-benda tersebut merupakan temuan lepas yang sudah kehilangan konteks asal.

\section{TIPOLOGI}

Pada umumnya beliung yang terdapat dalam koleksi tersebut termasuk dalam satu tipe, yaitu beliung persegi sederhana. Ciri-ciri yang dimiliki antara lain berbentuk memanjang dengan bidang depan dan belakang melebar dari hulu ke arah tajaman; penampang segi empat, bidang depan dan belakang cenderung melengkung cembung sehingga masing-masing bidang bertemu pada sudutsudut yang tumpul; bagian tajaman lebih lebar dari bagian pangkal dengan perubahan berangsur; tajaman satu muka (monofacial) dan dibentuk dengan pemangkasan miring dari ujung calon tajaman ke arah hulu: dalam beberapa hal lereng tajaman dibuat landai sehingga sering permukaan lereng terlihat samar; dalam hal lain lereng tersebut dibuat melengkung terjal mendekati tajaman. Jika dihubungkan dengan tipologi Duff (1970: 12) beliung ini tergolong dalam tipe II (simple rectangular) yang dianggap sebagai tipe asal dari semua tipe beliung.

Dari keseluruhan beliung di atas. tiga buah di antaranya (13 s/d 15 Lum/K) mempunyai bentuk lain dan tergolong sebagai variasi. Jika pada umumnya berbentuk memanjang (panjang sekitar $2 \times$ lebar), maka beliung ini mempunyai panjang yang tidak jauh berbeda dari lebarnya. Ukurannya juga tergolong kecil untuk ukuran beliung yang umum, yaitu panjang hanya sekitar $2,2-3,1 \mathrm{~cm}$ dan lebar antara 1.5-1,7 cm. Perbandingan antara panjang dan lebar yang hampir sama membuat beliung ini tampak tambun. Bagian pangkal hanya sebagian kecil dari keseluruhan beliung. bahkan lereng tajaman dimulai dari bagian hulu. Untuk beliung semacam ini pemasangan tangkai mengalami kesulitan mengingat sempitnya bidang tempat ikatan. oleh sebab itu cara-cara pengoperasiannya masih perlu dipertanyakan. Bentuknya yang tidak proporsional serta ukurannya yang tergolong kecil membuat beliung ini tergolong unik.

\section{TEKNOLOGI}

Dari segi fungsional, koleksi beliung Lumajang tergolong beliung yang sudah jadi dalam arti telah sampai pada tahap pemakaian, tetapi dari sudut pandangan 
teknologis koleksi tersebut masih dapat dibedakan antara beliung yang pengerjaannya telah sempurna dan beliung yang kurang sempurna. Untuk kategori pertama proses pengerjaan telah menyelesaikan tahap akhir, yaitu penggosokan (dan pengupaman) permukaan sehingga menampilkan hasil pengerjaan yang halus. Bentuknya juga tergolong proporsional dalam arti perbandingan antara panjang dan lebar tampak serasi dan demikian juga dengan bidang yang melebar simetris menuju tajaman. Permukaan bidang-bidang dikerjakan halus, diawali dengan penggosokan untuk menghilangkan bekas-bekas pangkasan berupa cekungan-cekungan pada tahap-tahap sebelumnya dan dilanjutkan dengan pengupaman untuk menciptakan permukaan yang halus dan berkilat.

Memang dalam beberapa hal terdapat bagian-bagian yang kurang halus. terutama pada bagian hulu seperti yang umum dijumpai pada beliung. Bagian ini masih meninggalkan bekas-bekas pangkasan dalam tahap-tahap pembentukan. Namun dari sudut teknolgis, kekasaran semacam ini dapat dimengerti dan tampaknya ada unsur kesengajaan dari artisan untuk dapat mengikat tangkai beliung dengan kuat. Semakin halus bagian tempat ikatan semakin sulit membuat ikatan yang kuat. Alasan inilah kemungkinan yang membuat pengerjaan terhadap bagian hulu beliung pada umumnya kasar. Kesan kekasaran yang lain terdapat di beberapa bagian dari permukaan berupa cekungancekungan yang tidak mampu dihilangkan melalui penggosokan. Hal semacam ini lebih sering disebabkan cekungan tersebut terlalu dalam sehingga tidak memungkinkan untuk dihilangkan.

Beliung yang tergolong kasar terdapat pada ketiga beliung variasi unik di atas dan tujuh buah beliung tipe umum. Kekasaran tampak pada pengerjaan permukaan yang tidak sempurna, bentuk yang tidak simetris, serta penyelesaian bagian hulu yang secukupnya. Penggosokan memang dilakukan terhadap permukaannya namun pengerjaan tahap akhir ini tidak sampai pada tingkat menghilangkan bekas-bekas pangkasan. sehingga di permukaannya masih tertinggal ceruk-ceruk atau cekungan-cekungan. Demikian juga pengerjaan terhadap bentuknya. tampak ketidak simetrisan dalam arti pelebaran bagian hulu ke arah tajaman tidak membentuk sudut yang sama, serta tidak lurus dan halus. sehingga kedua sisi mempunyai panjang yang berbeda. Bagian hulu dibiarkan kasar walaupun terlihat usaha penggosokan secukupnya.

Kekasaran beliung di atas agaknya tidak dapat didasarkan pada faktor kekasaran bahan seperti yang terdapat di situs perbengkelan Purbalingga ( $\mathrm{Si}$ - 
manjuntak 1985: 6), sebab bahan pembuatan beliung di atas pada umumnya terbuat dari batuan yang sama, yaitu basalt dan rijang. Jika alasan kesulitan dalam penggosokan, maka seluruh beliung akan berada pada tingkat penyelesaian yang tidak jauh berbeda. Dan oleh sebab itu. perbedaan tingkat pengerjaan ini agaknya lebih didasarkan pada faktor artisan semata.

Dalam hubungannya dengan proses pembuatan yang meliputinya. agak sulit untuk mengetahui tahap-tahap yang harus dilalui mengingat tidak ditemukan berbagai unsur perbengkelan lain dan beliung yang masih dalam tahap pengerjaan. Namun kekosongan ini agaknya dapat diisi dengan memperhatikan proses pembuatañ beliuing di situs perbengkelan Limbasari, Purbalingga. Di situs ini proses pembuatan beliung berlangsung secara lengkap mulai dari tahap pencarian bahan baku berupa bungkal-bungkal rijang dilanjutkan dengan tahap. tahap pembuatan hingga beliung dihasilkan. Secara umum tahap-tahap tersebut terdiri dari tahap pembentukan atau pemangkasan primer, tahap pengerjaan kedua kali atau pemangkasan sekunder, serta tahap penggosokan dan pengupaman (Simanjuntak 1984)

Dari keadaannya yang sudah dipergunakan hanya beberapa hal yang dapat disoroti dalam hubungannya dengan proses pembuatan. Tampak bentuk yarig diinginkan pada umumnya persegi dengan sisi yang melebar ke arah tajaman. Terlihat suatu kecenderungan untuk membentuk bidang depan dan belakang agak cembung sehingga beliung semacam ini akan membentuk penampang segi empat dengan sisi-sisi yang bertemu pada sudut-sudut tumpul. Tajaman satu muka dibuàt dengan membentuk lereng landai yang melengkung terjal di bagian ujung dengan cara pemangkasan miring dan diiringi dengan penggosokan. Jika lereng telah tercipta diiringi dengan penggosokan dan pengupaman untuk men ciptakan permukaan yang halus.

Pengamatan lebih lanjut memperlihatkan adanya kerusakan akibat pemakaian di bagian tajaman. Bekas-bekas pakai tersebut membentuk cekungan-cekungan dengan ukuran bervariasi dari yang tergolong halus (kurang dari $1 \mathrm{~mm}$ ) hingga yang tergolong besar (sekitar $1 \mathrm{~cm}$ ). Ukuran cekunyan-cekungan ini mena. rik perhatian dalam hubungannya dengan pemakaian beliung.

\section{Temuan lain}

Di muka telah disinggung, bahwa di samping beliung-beliung di atas ditemukan sebuah beliung yang belum selesai dikerjakan (calon beliung) dan se- 
buah batu asah. Calon beliung tersebut masih tebal, irisan berbentuk hampir bujur sangkar, tajaman sudah mulai tampak pada bidang depan walaupun belum selesai dikerjakan. Permukaan calon beliung ini sudah mulai diasah. Ciri lain yang terlihat antara lain, hulu masih lebih lebar dari tajaman dan tajaman masih tumpul. Penemu tidak diketahui, tetapi menurut keterangan Seksi Kebudayaan Departemen Pendidikan dan Kebudayaan Lumajang ditemukan dari daerah Senduro bersamaan dengan beliung-beliung di atas. Panjang calon beliung ini $5.8 \mathrm{~cm}$, lebar hulu $3.1 \mathrm{~cm}$, lebar tajaman $2,7 \mathrm{~cm}$. dan tebal $2.5 \mathrm{~cm}$.

Batu asah (17/Lum/K) berbentuk empat persegi kasar dengan salah satu sisinya melengkung akibat penggosokan. Hal yang sama terdapat pada permukaan bidang datarnya yang membentuk cekungan. Jika dihubungkan dengan lokasi penemuan yang seasal dengan beliung-beliung di atas, agaknya batu asah ini berperan dalam proses pembentukan beliung. Batu asah dengan permukaan aus akibat penggosokan dalam pembuatan beliung pernah ditemukan di situs Limbasari, Purbalingga (Truman Simanjuntak 1983 : 48). Panjang batu asah ini $9,7 \mathrm{~cm}$. lebar $6 \mathrm{~cm}$, tebal $3 \mathrm{~cm}$. dan tebal cekungan $1.7 \mathrm{~cm}$.

Pada waktu ekskavasi Biting sedang berlangsung, seorang penduduk menunjukkan sebuah beliung kepada tim yang dikatakan berasal dari tegalannya di Desa Pandansari. Kecamatan Klakah. Kabupaten Probolinggi. Bentuknya empat persegi dengan sisi-sisi bertemu pada sudut-sudut tumpul, bagian belakang lebih lebar dari bagian depan. Penggosokan dan pengupaman telah dilakukan pada seluruh permukaan, kecuali bagian hulu. Tajaman dibentuk dengan memangkas bidang depan beliung ke arah hulu. Agaknya telah digunakan secara intensip seperti tampak pada pecahan-pecahan halus dan kasar pada ta jaman tersebut. Bahan dari batuan berwarna hitam kehijau-hijauan Panjang $6 \mathrm{~cm}$. panjang lereng $2,2 \mathrm{~cm}$. lebar hulu $3.5 \mathrm{~cm}$. lebar tajaman $4.6 \mathrm{~cm}$. dan tebal bilah $1.3 \mathrm{~cm}$.

\section{BEBERAPA CATATAN}

Penemuan beliung-beliung di atas merupakan data baru untuk distribusi beliung di Jawa. Selama ini belum ada laporan tentang penemuan beliung di daerah Lumajang. Berkat penemuan ini dapat ditarik suatu daerah persebaran yang memanjang di bagian selatan Jawa Timur, yaitu mulai dari daerah Malang selatan (Soejono 1975 : 165) menuju daerah Lumajang hingga Kendeng 
Lembu, Jember. Suatu hal yang belum diketahui dalam kaitannya dengan konteks penemuan, yaitu apakah beliung tersebut dibuat di tempat penemuan atau didatangkan dari luar. Data perbengkelan yang ditemukan masih sangat sedikit, yaitu hanya sebuah batu asah sedang data umum berupa tatal-tatal batu belum diketahui, berhubung belum diadakan survei di daerah penemuan. Untuk menjawab pertanyaan tersebut diperlukan penelitian di daerah penemuan, sehingga hasil yang didapat akan memberi gambaran yang lebih jelas, tidak terbatas pada kontekstual melainkan juga artefaktual.

Di balik ketidak-lengkapan data di atas, penemuan-penemuan tersebut cukup penting untuk memberi gambaran tentang beberapa hal yang menyangkut tipologi, teknologi, dan sedikit fungsional. Dari sudut tipologi, beliung Lumajang termasuk dalam satu tipe, yaitu beliuang persegi sederhana. Beliung semacam ini paling umum dijumpai di daerah Asia Tenggara. Dari berbagai variasinya selalu ditemukan di ketiga daerah persebaran beliung yang meliputi daerah persebaran I (China Selatan-Formosa Filipina), daerah persebaran II (VietnamLaos-Kamboja-Thailand Utara), serta daerah persebaran III (Thailand SelatanMalaya-Indonesia) (Duff 1970 : 13).

Dari segi hasil akhir, pengerjaan terhadap beliung ini mempunyai intensitas yang berbeda. Beberapa dikerjakan secara intensip hingga tercapui suatu beliung yang halus dan indah, sedang sebagian lainnya dikerjakan tidak seintensip yang pertama sehingga dihasilkan suatu beliung yang kasar. Terjadinya perbedaan-perbedaan dalam bentuk dan tingkat pengerjaan di atas dapat dipengaruhi oleh beberapa faktor, antara lain konsepsi si pembuat (mental template), bahan baku (raw material), dan kemampuan menerima unsur luar dan memadukannya dengan unsur asli hingga tercipta suatu unsur baru perpaduan keduanya (local genius).

Faktor konsepsi sangat menentukan dalam hasil akhir suatu pekerjaan. Sebelum pengerjaan, si pembuat telah mempunyai gambaran tentang benda yang akan dibuat serta teknik-teknik yang akan diterapkan di dalam mewujud. kannya (Deetz 1967 : 45), sehingga di dalam pelaksanaan, tangan-tangan si pembuat dikendalikan oleh konsepsi tersebut. Memang tidak sepenuhnya konsepsi tersebut terwujud disebabkan beberapa faktor di luar kemampuan si pem. buat, namun hasil yang dicapai paling tidak mendekati bentuk yang diinginkan. Salah satu faktor yang mempengaruhi bentuk yang dihasilkan adalah keahlian si pembuat. Semakin ahli seseorang, benda yang dihasilkan lebih cenderung 
mendekati konsepsinya dan demikian sebaliknya.

Bahan baku ikut berperan dalam menentukan hasil akhir suatu benda yang dibuat, jika lingkungan tempat pembuatan hanya menyediakan bahan yang terbatas. Ada kemungkinan suatu lingkungan tidak menyediakan bahan baku yang dapat mewujudkan konsepsi si pembuat, sehingga benda yang dihasilkan disesuaikan dengan bahan yang tersedia. Dalam kaitannya dengan bentuk unik beliung Lumajang, faktor ini tampaknya kurang berperan mengingat ditemukannya juga beliung yang berukuran besar.

Faktor yang terakhir adalah "local genius" yang menunjukkan kemampuan masyarakat setempat untuk mengolah kebudayaan yang masuk menjadi suatu bentuk baru dan dikembangkan secara lokal, sehingga bentuk semacam ini merupakan ciri budaya setempat yang tidaak ditemukan di tempat lain. Untuk beliung unik di atas ada kemungkinan faktor inilah yang lebih berperan sehingga artisan membuat beliung berukuran-kecil tanpa menghilangkan ciri-ciri tipe umum.

Dari segi teknologis, pembuatan beliung Lumajang di atas memperlihatkan penerapan teknik campuran. Hal seperti ini umum dalam pembuatan suatu benda agar dicapai hasil yang diinginkan (Crabtree 1972 : 3). Pembuatan dilakukan terlebih dahulu dengan pemangkasan bahan baku dari berbagai sisi untuk menghasilkan bentuk dasar beliung. Penerapan teknik pemangkasan langsung atau tidak langsung tidak diketahui secara jelas mengirigat tidak ditemukannya calon beliung yang proses pengerjaannya masih dalam tahap pembentukan, namun biasanya kedua teknik ini diterapkan dalam pembentukan suatu beliung (Truman Simanjuntak 1984).

Setelah bentuk dasar tercapai dilanjutkan dengan tahap penyelesaian berupa penggosokan seluruh permukaan (kecuali bagian hulu) hingga rata. Adakalanya penggosokan yang dilakukan berhasil sempurna hingga permukaan yang tadinya kasar dengan ceruk atau cekungan-cekungan pemangkasan berubah menjadi rata. Tetapi ada pula kalanya cekungan-cekungan masih terlihat di beberapa bagian walaupun penggosokan telah dilakukàn seintensif mungkin. Hal semacam ini dapat terjadi jika cekungan terlalu dalam sehingga tidak mungkin dihilangkan dengan penggosokan, sebab jika diteruskan akan mengakibatkan beliung terlampau tipis. Dalam kasus semacam ini kekasaran terjadi akibat kesalahan teknik di dalam tahap-tahap pemangkasan. 
Penggosokan tampaknya dilakukan dengan bantuan dari jenis lain seperti tampak pada temuan sebuah batu asah dalam konteks penemuan beliung di atas. Terbuat dari batu pasir berwarna keabu-abuan, permukaannya aus dan membentuk cekungan akibat kegiatan penggosokan.

Setelah penggosokan berakhir biasanya diikuti dengan pengupaman (polishing) untuk menciptakan permukaan yang halus, licin, dan berkilat. Hasil pengupaman tidak sama terhadap semua beliung tergantung pada bahan pembuatan. Biasanya hasil yang lebih baik akan diperoleh pada beliung dari batuan keras dan berbutir halus.

Dari segi fungsional hampir semua beliung menunjukkan tanda-tanda pemakaian. Ciri yang paling mudah dikenal adalah tajaman yang rusak (pecahpecah) membentuk cekungan halus hingga kasar. Cekungan-cekungan tersebut tidak berpola teratur tetapi berbeda-beda pada setiap beliung. Sebagian beliung menunjukkan cekungan yang sangat padat di seluruh tajaman, tetapi sebagian lainnya hanya di beberapa bagian dan bahkan hanya berupa cekungan halus. Keberadaan cekunyan ini memberi petunjuk tentang intensitas pemakaian. Ada beliung yang intensif digunakan seperti ditunjukkan oleh cekungan-cekungan yang padat dan ada yang kurang intensif seperti ditunjukkan oleh pecahanpecahan halus di sekitar tajaman. Tentang penggunaannya belum diketahui, namun melihat pecahan tajaman yang kasar agaknya berhubungan dengan benda keras, seperti kayu, batu dan lain-lain. Penelitian yang lebih mendalam tentang fungsi beliung ini masih diperlukan untuk masa mendatang. 


\section{DAFTAR BACAAN}

Duff, Roger, 1970. Fhe stone adzes of Southeast Asia, New Zealand: Canterburry Museum.

Deetz, James, 1967. Invitation to Archaeology, New York: Fhe Natural History Press.

Crabtree, Don E., 1972. An Introduction to the technology of stone tools, tanpa penerbit.

Simanjuntak. F, dkk, 1983. Laporan Penelitian Arkeologi Limbasari, dalam penerbitan.

Simanjuntak. F, dkk, 1984. Adze manufacturing at Limbasari workshop site, paper presented at the first Van Heekeren Symposium, Yogyakarta.

Simanjuntak. F, dkk, 1985. Perbengkelan Neolitik Purbalingga, dalam penerbitan.

Soejono, RP, dkk. 1975. Sejarah Nasional Indonesia I. Jakarta: Departemen P dan $\mathrm{K}$. 


\begin{tabular}{|c|c|c|c|}
\hline No. Benda & $B e n t u k$ & Tajaman & Penyelesaian \\
\hline 1/Lum/K & $\begin{array}{l}\text { Memanjang dan melebar simetris ke } \\
\text { arah tajaman. Penampang segi em- } \\
\text { pat, bidang depan dan belakang } \\
\text { agak cembung. }\end{array}$ & $\begin{array}{l}\text { Lereng landai, melengkung terjal di } \\
\text { bagian ujung. Cekungan kasar me- } \\
\text { nyebar di sepanjang permukaan. }\end{array}$ & $\begin{array}{l}\text { Permukaan digosok dan diupam ha. } \\
\text { lus. kecuali beberapa cekungan di be. } \\
\text { berapa bagian. }\end{array}$ \\
\hline 2/Lum/K & $\begin{array}{l}\text { Memanjang dan melebar simetris ke } \\
\text { arah tajaman. Penampang segi em- } \\
\text { pat, bidang depan dan belakang } \\
\text { agak cembung. }\end{array}$ & $\begin{array}{l}\text { Lereng landai, melengkung terjal di } \\
\text { bagian ujung. Cekungan kasar ter- } \\
\text { utama di sudut-sudut tajaman. }\end{array}$ & $\begin{array}{l}\text { Permukaan kasar terutama pada bi- } \\
\text { dang depan. Bidang lainnya tergo- } \\
\text { long halus. }\end{array}$ \\
\hline 3/Lum/K & $\begin{array}{l}\text { Memanjang dan melebar tidak sime- } \\
\text { tris ke arah tajaman. Penampang } \\
\text { segi empat, bidang depan dan bela- } \\
\text { kang agak cembung. }\end{array}$ & $\begin{array}{l}\text { Lereng landai dan lurus. Cekungan } \\
\text { halus dan kasar menyebar di permu- } \\
\text { kaan. }\end{array}$ & $\begin{array}{l}\text { Permukaan digosok dan diupam ha- } \\
\text { lus. beberapa cekungan terlihat di sa- } \\
\text { lah satu sisi. }\end{array}$ \\
\hline 5/Lum/K & $\begin{array}{l}\text { Memanjang dan sedikit melebar si- } \\
\text { metris ke arah tajaman. Penampang } \\
\text { segi empat, bidang depan dan bela- } \\
\text { kang agak cembung. }\end{array}$ & $\begin{array}{l}\text { Lereng landai, melengkung terjal di } \\
\text { bagian ujung. Cekungan kasar me- } \\
\text { nyebar di sepanjang permukaan. }\end{array}$ & $\begin{array}{l}\text { Permukaan digosok dan diupam ha. } \\
\text { lus, terutama bidang belakang. }\end{array}$ \\
\hline 6/Lum/K & $\begin{array}{l}\text { Memanjang dan melebar tidak sime- } \\
\text { tris ke arah tajaman. Penampang } \\
\text { segi empat tebal dengan sisi-sisi } \\
\text { cembung. }\end{array}$ & $\begin{array}{l}\text { Lereng landai, lurus. Cekungan ka- } \\
\text { sar menyebar di sepanjang permuka- } \\
\text { an. }\end{array}$ & $\begin{array}{l}\text { Permukaan digosok dan diupam ha- } \\
\text { lus. }\end{array}$ \\
\hline 7/Lum/K & $\begin{array}{l}\text { Memanjang dan melebar tidak sime- } \\
\text { tris ke arah tajaman. Penampang } \\
\text { segi empat. tidang depan dan bela- } \\
\text { kang agak cembung. }\end{array}$ & $\begin{array}{l}\text { Lereng landai dan lurus. Cekungan } \\
\text { halus menyebar di sepanjang per- } \\
\text { mukaan. } \\
\text { s://doi.org/10.30883/jba.v6i2.439 }\end{array}$ & $\begin{array}{l}\text { Permukaan digosok dan diupam ha- } \\
\text { lus tetapi cekungan bekas pangkasan } \\
\text { masih tertinggal di beberapa bagian. }\end{array}$ \\
\hline
\end{tabular}




\begin{tabular}{|c|c|c|c|}
\hline 8/Lum/K & $\begin{array}{l}\text { Memanjang dan melebar tidak sime- } \\
\text { tris ke arah tajaman. Penampang } \\
\text { segi empat, bidang depan dan be- } \\
\text { lakang agak cembung. }\end{array}$ & $\begin{array}{l}\text { Lereng landai dan lurus. Cekungan } \\
\text { halus menyebar di sepanjang permiu- } \\
\text { kaan }\end{array}$ & $\begin{array}{l}\text { Permukaan digosok dan diupam ha- } \\
\text { lus, tetapi cekunganbekas pangkasan } \\
\text { masih tertinggal banyak terutama di } \\
\text { bidang depan. }\end{array}$ \\
\hline 9/Lum/K & $\begin{array}{l}\text { Memanjang dan melebar tidak sime- } \\
\text { tris ke arah tajaman. Penampang } \\
\text { segi empat, bidang belakang agak } \\
\text { cembung. }\end{array}$ & $\begin{array}{l}\text { Lereng tejal. Cek } \\
\text { kasar di sebagian be }\end{array}$ & $\begin{array}{l}\text { Permukaan digosok secukupnya se- } \\
\text { hingga masih kasar. }\end{array}$ \\
\hline 10/Lum/K & $\begin{array}{l}\text { Memanjang dan melebar tidak sime- } \\
\text { tris ke arah tajaman. Penampang } \\
\text { segi empat, bidang depan dan bela- } \\
\text { kang agak cembung. }\end{array}$ & $\begin{array}{l}\text { Lereng landai dan terjal di bagian } \\
\text { ujung. Cekungan kasar menyebar di } \\
\text { sepanjang permukaan. }\end{array}$ & $\begin{array}{l}\text { ok secukupnya se- } \\
\text { ar. }\end{array}$ \\
\hline 11/Lum/K & $\begin{array}{l}\text { Memanjang dan melebar tidak sime- } \\
\text { tris ke arah tajaman. Penampang } \\
\text { segi empat tebal, bidang depan dan } \\
\text { belakang cembung. }\end{array}$ & $\begin{array}{l}\text { Lereng terjal. Cekungan halus } \\
\text { kasar di beberapa bagian taja } \\
\text { kasar di beherapa bagian tajar }\end{array}$ & $\begin{array}{l}\text { Permukaan digosok secukupnua se- } \\
\text { hingga masih kasar. }\end{array}$ \\
\hline 12/Lum/K & $\begin{array}{l}\text { Memanjang dan melebar tidak sime- } \\
\text { tris ke arah tajaman. Penampang } \\
\text { segi empat, bidang depan dan bela- } \\
\text { kang agak cembung. }\end{array}$ & $\begin{array}{l}\text { Lereng landai dan lurus. Cekur } \\
\text { halus terutama di salah satu s } \\
\text { tajaman. }\end{array}$ & $\begin{array}{l}\text { Permukaan digosok secukupnya, se- } \\
\text { hingga masih kasar. }\end{array}$ \\
\hline 13/Lum/K & $\begin{array}{l}\text { Tambun dan melebar tidak simetris } \\
\text { ke arah tajaman. Penampang segi } \\
\text { empat, bidang depan dan belakang } \\
\text { cembung. }\end{array}$ & $\begin{array}{l}\text { erjal. Cekungan kasar di se- } \\
\text { permukaan. }\end{array}$ & $\begin{array}{l}\text { Permu } \\
\text { cukupr } \\
\text { masih }\end{array}$ \\
\hline 14/Lum/K & $\begin{array}{l}\text { Tambun dan melebar tidak simetris } \\
\text { ke arah tajaman. Penampang segı } \\
\text { empat, bidang depan dan belakang } \\
\text { agak cembung. }\end{array}$ & $\begin{array}{l}\text { Lereng landai, melengkung terjal di } \\
\text { bagian ujung. Cekungan halus di se- } \\
\text { bagian permukaan. }\end{array}$ & $\begin{array}{l}\text { Permukaan digosok dan diupam ha- } \\
\text { lus, tetapi kekasaran masih tampak } \\
\text { berupa bekas-bekas penger jaan sebe- } \\
\text { lumnya. }\end{array}$ \\
\hline 15/Lum/K & $\begin{array}{l}\text { Tambun dan melebar tidak simetris } \\
\text { ke arah tajaman. Penampang segi } \\
\text { empat, bidang depan dan belakang } \\
\text { agak cembung. }\end{array}$ & $\begin{array}{l}\text { Lereng landai, melengkung terjal di } \\
\text { bagian ujung. Cekungan halus di se- } \\
\text { bagian permukaan. }\end{array}$ & $\begin{array}{l}\text { Permukaan.digosok dan diupam ha- } \\
\text { lus, tetapi kekasaran masih tampak } \\
\text { berupa bekas-bekas penger jaan sebe- } \\
\text { lumnya. }\end{array}$ \\
\hline
\end{tabular}




\section{LAMPIRAN FOTO H. TRUMAN SIMANUUNTAK}

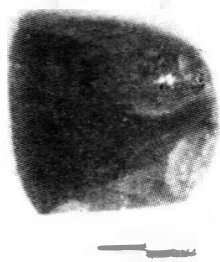

Foto 1. Beliung berbentuk Tambun dan kecil (14/Lum/K) dilihat dari depan)

Foto 2. Beliung berbentuk tambun (14/ Lum/K) dilihat dari samping. 


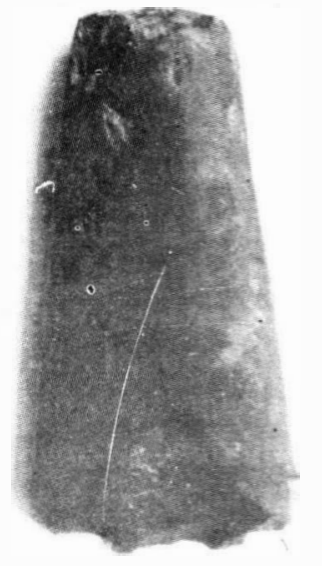

\section{1}

Foto 3. Beliuang persegi dengan pengerjaan yang halus ( $1 / \mathrm{Lum} / \mathrm{K})$ dilihat dari depan.

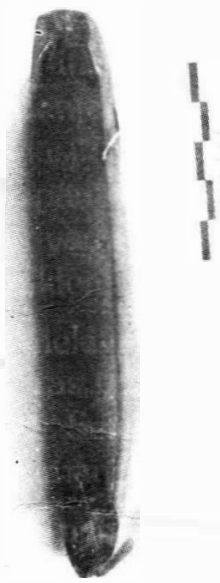

Foto 4. Beliuang persegi (1/Lum/K) dilihat dari samping. 


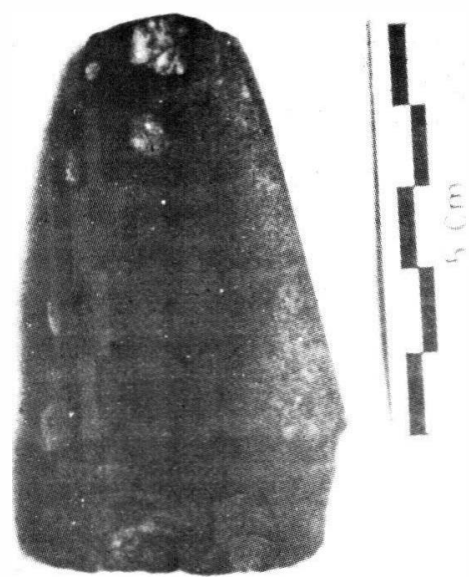

Foto 5. Beliuang persegi dengan pengerjaan kasar dilihat dari depan. (9/ Lum/K).

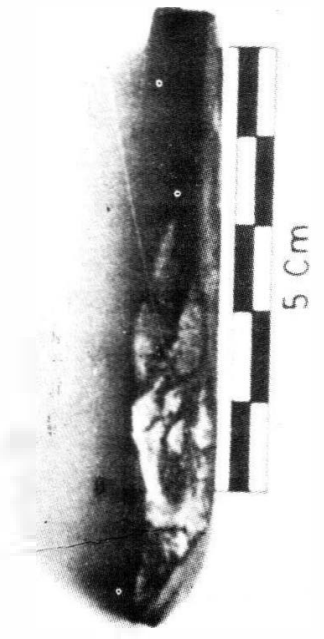

Foto 6. Beliuang persegi $(9 / \mathrm{Lum} / \mathrm{K})$ dilihat dari samping. 